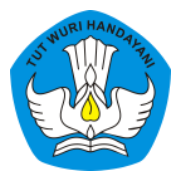

Page: 319-334

\title{
PEMANFAATAN PELEPAH SAWIT DALAM PEMBELAJARAN CERMIN DI SMP NEGERI 5 SATU ATAP TANJUNG MORAWA
}

\author{
Rusti Lumban Gaol \\ Sekolah Menengah Pertama Negeri 5 Satu Atap Tanjung Morawa \\ Contributor Email: rstlg@ymail.com
}

Published: Juli 30, 2020

Article Url: https://ojsdikdas.kemdikbud.go.id/index.php/didaktika/article/view/122

\begin{abstract}
Palm oil fronds can be utilized in the learning of flat, concave and convex mirrors. The development of palm frond mirror media is a solution because of the unavailability of tools that support learning and science laboratories. The research objective is to develop a palm oil frond mirror media so that it can be used in the learning process of flat, concave and convex mirror, and improve student learning outcomes by using the palm frond mirror media in discovery learning. The method used with the ADDIE model. The results of the study explained that the use of palm frond mirror media could improve student learning outcomes namely $X^{-}=33.72$ to $X^{-}=82.08 \mathrm{~g}=0.72$ (high category), with students who had previously completed 6\% to $89 \%$. Palm frond mirror media is suitable for use in learning. This learning media is also effective in creating a pleasant atmosphere, students are active because they are directly involved in the process of making tools and concept discovery. The development of the media of palm frond mirror is able to build the character of students' scientific attitudes, namely discipline, honesty, care for the environment, and cooperation.
\end{abstract}

Keywords: Utilization, Palm Midrib, Mirror Learning 


\begin{abstract}
Abstrak
Pelepah kelapa sawit dapat dimanfaatkan dalam pembelajaran cermin datar, cekung, dan cembung. Pengembangan media cermin pelepah sawit menjadi solusi karena tidak tersedianya alat-alat yang mendukung pembelajaran dan laboratorium IPA. Tujuan penelitian adalah untuk mengembangkan media cermin pelepah kelapa sawit sehingga dapat digunakan dalam proses pembelajaran cermin datar, cekung dan cembung, seta meningkatkan hasil belajar siswa dengan cara penggunaan media cermin pelepah sawit pada pembelajaran discovery learning. Metode yang digunakan dengan model ADDIE. Hasil penelitian menjelaskan bahwa penggunaan media cermin pelepah sawit dapat meningkatkan hasil belajar siswa yaitu $\bar{X}=33,72$ menjadi $\bar{X}=82,08 g=0,72$ (kategori tinggi), dengan siswa yang tuntas sebelumnya 6 $\%$ menjadi $89 \%$. Media cermin pelepah sawit layak digunakan dalam pembelajaran. Media pembelajaran ini juga efektif menciptakan suasana menyenangkan, siswa aktif karena terlibat langsung dalam proses pembuatan alat dan penemuan konsep. Pengembangan media cermin pelepah sawit ini mampu membangun karakter sikap ilmiah siswa yaitu disiplin, jujur, perduli lingkungan, dan kerjasama.
\end{abstract}

Keywords: Pemanfatan, Pelepah Sawit, Pembelajaran Cermin

\title{
A. Pendahuluan
}

Pembuatan media pembelajaran dari bahan lingkungan alam sekitar bisa menjadi alternatif dalam pembelajaran IPA, sehingga kendalakendala belajar dalam pembelajaran cermin dapat diatasi, siswa dapat memahami konsep cermin dengan benar. Media pembelajaran dapat digunakan sebagai bahan praktikum siswa dalam memahami konsep cermin. Pemanfaatan lingkungan sekitar dalam pembelajaran cermin adalah dengan menggunakan pelepah kelapa sawit dan kaleng bekas.

Ternyata tidak selamanya praktikum harus menggunakan peralatan dari laboratorium yang mahal, tetapi bisa menggunakan lingkungan sekitar dengan biaya yang relatif murah. Pembelajaran IPA berkaitan dengan lingkungan sekitar. Benda di sekitar dapat digunakan sebagai alat dan bahan untuk menjelaskan fenomena sains di sekitar. 
Pembuatan media pembelajaran dari bahan lingkungan alam sekitar bisa menjadi alternatif dalam pembelajaran IPA, sehingga kendala- kendala belajar dalam pembelajaran cermin dapat diatasi, siswa dapat memahami konsep cermin dengan benar. "Media pembelajaran adalah benda atau alat yang digunakan untuk menyampaikan informasi dalam pembelajaran sehingga dapat menarik minat siswa dalam belajar" (Arsyad, 2015 : 10). Media pembelajaran dapat digunakan sebagai bahan praktikum siswa dalam memahami konsep cermin.

Media pembelajaran yang tepat akan menciptakan komunikasi yang efektif anatar guru dan siswa, sehingga dapat menghilangkan kejenuhan (kebosanan), pembelajaran menjadi menarik sehingga siswa antusias mengikuti pembelajaran. Pembelajaran dengan media cermin akan efektif dalam mengajarkan materi sehingga konsep cermin dan sifat bayangan akan di pahami siswa dengan tepat dan dapat diterapkan.

Salah satunya yang membuat kurang motivasi siswa dalam belajar yaitu (1) di rumah siswa sudah capek kerja, jadi ketika di sekolah siswa cenderung mengantuk atau mengobrol dengan teman ketika pembelajaran berlangsung, (2) laboratorium IPA tidak tersedia, kurangnya alat-alat untuk melakukan praktikum, (3) siswa takut belajar IPA karena dianggap sulit, dari konsep dan hitungan matematikanya, (4) siswa dituntut menghafal teori, rumus dan mengerjakan sosal sesuai rumus sehingga siswa tidak memahami konsep, (5) siswa kurang kreatif karena pembelajaran kurang menarik dan tidak melibatkan siswa. Kendala lain adalah ditemukan adanya permasalahan berkaitan dengan guru. Berdasarkan wawancara dengan guru bahwa selama ini kegiatan 
proses pembelajaran dilaksanakan dengan metode ceramah dan berpusat pada guru (teacher centered), guru kurang kreatif memanfaatkan lingkungan sekitar dan mengadopsi bahan ajar dari internet.

Tujuan pembelajaran tidak tersampaikan dengan baik diakibatkan pembelajaran satu arah, interaksi antara guru dan siswa kurang. Pada kegiatan pembelajaran IPA materi cermin seharusnya siswa dapat mengalami pengalaman langsung dalam mengembangkan kompetensinya dengan memanfaatkan alam sekitar secara science. Pendidikan IPA merupakan proses menemukan sehingga memudahkan siswa dalam memperoleh pengetahuan atau pemahaman tentang lingkungan alam sekitar. "Pembelajaran IPA di SMP adalah untuk mempelajari gejala-gejala dengan proses ilmiah, dasar sikap ilmiah yang hasilnya terwujud dengan produk ilmiah tersusun tiga komponen yaitu konsep prinsip dan teoritis yang berlaku" (Trianto, 2010 : 141).

Pada pelaksaanaan pembelajaran media pelepah kelapa sawit dibutuhkan suatu model pembelajaran yang mampu meningkatkan aktivitas dan hasil belajar siswa. Model discovery learning mendorong siswa untuk mengembangkan pengetahuannya. Konsep diperoleh dari proses mengkonstruksi pengetahuan, sehingga konsep yang keliru dalam materi cermin dapat dihindari. Dengan model discovery learning membuat siswa lebih kreatif dengan berkarya, mengajukan pendapat, menganalisis, menyimpulkan dan membuat hipotesis. Siswa didorong mandiri di dalam belajar.

Inovasi pembelajaran dengan membuat media pembelajaran dari pelepah kelapa sawit dalam pembelajaran cermin datar, cermin cekung dan cembung dengan model discovery learning pada kelas $\mathrm{VIII}_{2}$ semester II Tahun Ajaran 2017/2018 di SMP Negeri 5 Satap Tanjung Morawa. Ada 3 
bagian pelepah kelapa sawit yaitu petiole (pangkal batang), rachis (batang tempat munculnya daun), dan leaflets (daun). Bagian pelepah kelapa sawit yang digunakan adalah (1) rachis (batang tempat munculnya daun) untuk cermin, (2) leaflets (daun) digunakan untuk lidi atau arah berkas cahaya.

\section{B. Metode}

Motode yang digunakan dalam membuat media cermin pelepah sawit adalah research and development (R\&D), pelaksanaan penelitian ini mengacu terhadap model ADDIE Model. (Taylor,2007:) yaitu Analysis-DesignDevelopment-Implementation-Evaluation. Dick dan Carey memberikan acuan untuk mengembangkan pembelajaran. dalam peneltian pengembangan terdiri dari Analysis-Design-Development-Implementation-Evaluation. (Dick dan Carey, 2005). Pendekatan dengan model ini dipilih karena pendekatan ini dapat diterapkan baik pada pendidikan formal, maupun pendidikan non formal dan juga model ini cocok untuk mengembangkan pengetahuan dan keterampilan pembuatan media cermin.

Prosedur penelitian pada tahap model ADDIE adalah

1. Tahap Analysis

Dilakukan analisa terhadap permasalahan yang meliputi analisa kebutuhan dengan observasi langsung kepada guru IPA di satu MGMP Tanjung Morawa dan juga kepada siswa SMP Negeri 5 Tanjung Morawa, juga analisis peralatan yang mendukung untuk melakukan percobaan. Hal ini dilakukan untuk menyesuaikan materi dengan silabus sehingga tercapai tujuan pembelajaran.

2. Tahap Design

Pada tahap ini dilakukan perancangan pengembangan media 
pelepah kelapa sawit berupa rancangan awal yang sesuai dengan analisa yang telah dilakukan sebelumnya. penerapan pembelajaran discovery learning pada materi cermin dengan media pelepah kelapa sawit dilkakukan dalam pembelajaran. Hasil dari tahap desain adalah:

- Design media pelah sawit yaitu media cermin datar, cekung, dan cembung

- Penerapan model discovery learning dalam pembelajaran

3. Tahap Development

Pada tahap ini dilakukan cara membuat media cermin dari pelepah kelapa sawit untuk cermin data, cekung dan cembung. Pada tahap ini dibuat LKS (lembar kerja siswa) sebagai penuntun siswa ketika melakukan praktikum. Media cermin yang dikembangkan sudah divalidasi ole Dr. Ridwan Sani, M.Pd sebagai Dosen Pendidikan Fisika UNIMED.

\section{Tahap Implementation}

Pada tahap ini media cermin dari pelepah kelapa sawit yang dikembangkan di uji cobakan pada siswa Kelas VIII-2 SMP Negeri 5 Satu Atap Tanjung Morawa berjumlah 36 orang dengan penerapan model discovery learning.

\section{Tahap Evaluation}

Pada tahap ini, dilakukan evaluasi secara keseluruhan kegiatan yang telah dilakukan, dengan evaluasi.

\section{Hasil dan Pembahasan}

Pembuatan media cermin pelepah sawit dibuat dari bahan sekitar lingkungan, kaleng bekas yang mudah didapat, dan ramah lingkungan. Hasil dari pengembangan media media cermin pelepah sawit berupa media cermin datar, cekung dan cembung yang mudah digunakan dan dipahami konsepnya. 
Rancangan karya inovasi dapat diuraikan berikut ini :alat dan bahan yang digunakan untuk pembuatan media cermin datar, cekung dan cembung adalah:

1. Pelepah kelapa sawit

2. Kaleng Bekas

3. Pisau/Cutter, Gergaji

4. Lem Setan

5. Senter
6. Rol Meter

7. Martil

8. Paku

9. Cat warna putih dan merah

10. Kapas

\section{Uji Coba dan Revisi Produk}

Media cermin pelepah sawit ini masih memodelkan arah berkas cahaya pada cermin datar (sejajar), cermin cekung (konvergen), cermin cembung (divergen). Sehingga siswa kesulitan memahami jarak benda, titik fokus, titik pusat kelengkungan cermin dan jarak bayangan. Siswa juga belum memahami pembentukan bayangan pada cermin datar, cekung dan cembung. Media ini kemudian direvisi dengan menggunakan kaleng bekas untuk menjelaskan konsep pemantulan cahaya, sehingga siswa dapat memahami konsep cermin dengan benar.

Media Pelepah Sawit dengan Menggunakan Kaleng bekas untuk Pemantulan Cahaya. Langkah-langkah pembuatan media cermin pelepah sawit dengan kaleng bekas yaitu :

1. Bersihkan kaleng bekas kemudian digunting sebanyak 3 buah dengan panjang $40 \mathrm{~cm}$ lebar antara $5-7 \mathrm{~cm}$ disesuaikan lebar pelepah sawit

2. Tempelkanlah kaleng bekas yang sudah dibentuk pada batang pelepah kelapa sawit yang sudah dibentuk dengan menggunakan kapas dan lem setan.

3. Media cermin pelepah sawit yang sudah terbentuk 


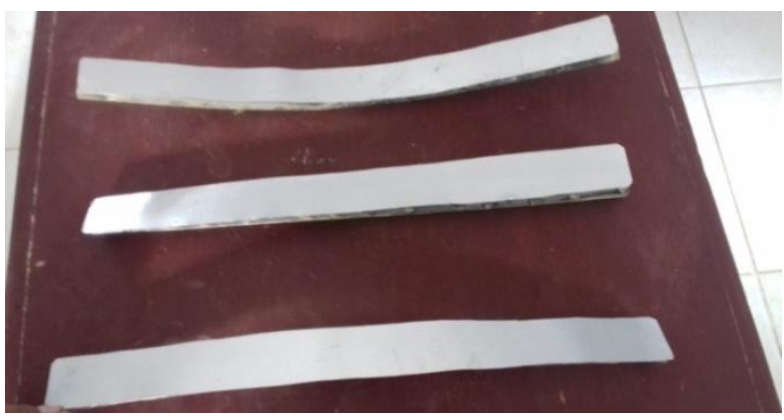

Gambar 1.

Produk Media Cermin Cekung, datar, dan Cembung

\section{Hasil Pengembangan Media Cermin}

\section{Cermin Datar}
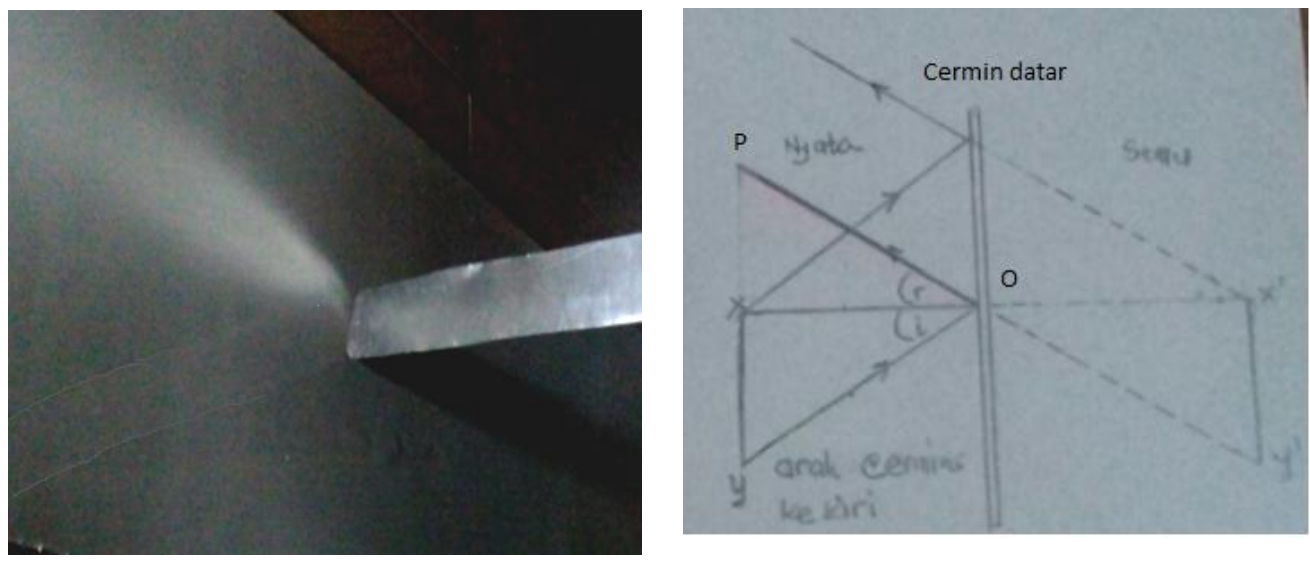

Gambar 2.

Hasil Temuan Media Cermin Datar

Keterangan :

- Bayangan nyata berada di depan cermin, titik $x$ adalah titik sumber cahaya, $\mathrm{x}=$ objek, cahaya yang mencapai media cermin dari $\mathrm{X}$ memantul dari kaleng bekas. 
- Bayangan maya berada di belakang cermin, $\left(x^{\prime}\right)$,

- Sinar datang, sinar pantul, garis pantul berpotongan pada satu bidang titik

- Dari gambar diatas berkas sinar yang mengenai cermin membentuk segitiga siku-siku yang sama yaitu o-x-y dan $x-0-p$ dengan sudut yang sama yaitu Sudut datang $(\mathrm{i})=$ sudut pantul $(\mathrm{r})$

- Sifat bayangan pada cermin datar adalah semu, tegak dan diperbesar

\section{Cermin Cekung}
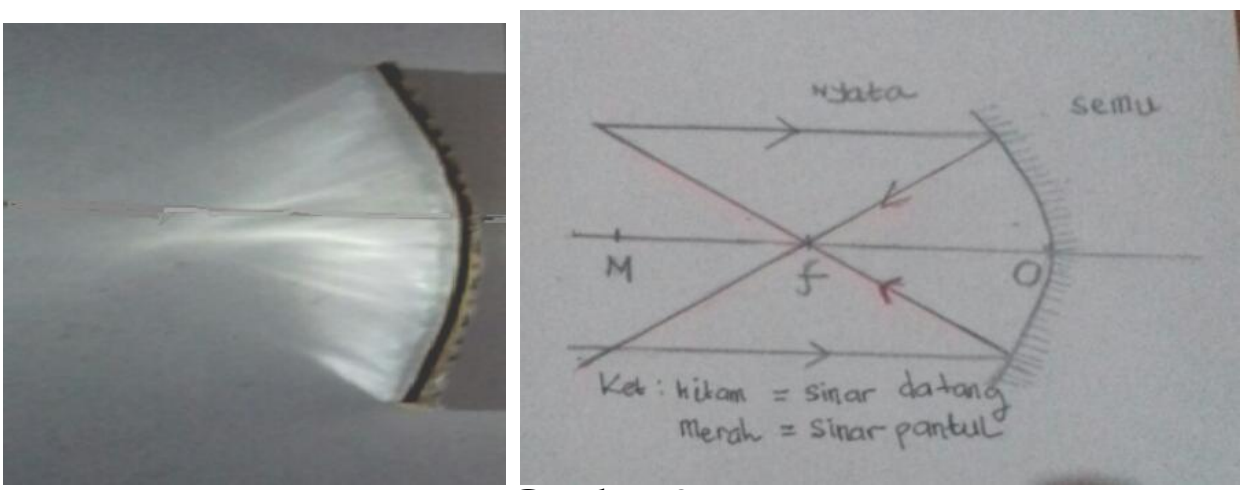

Gambar 3.

Hasil Temuan Media Cermin Cekung

- Cermin cekung bersifat konvergen yaitu mengumpulkan cahaya atau berpusat pada satu titik yang disebut titik fokus (f)

- Titik fokus terletak di daerah nyata (depan cermin) sehingga sering disebut cermin positif $(\mathrm{f}=+)$

- 3 sinar istimewa (1) sinar datang sejajar sumbu utama dipantulkan melalui titik fokus, (2) sinar datang yang melalui titik fokus (f) mengenai permukaan cermin akan dipantulkan sejajar sumbu utama, dan (3) sinar datang melalui titik kelengkungan cermin, dipantulkan ke titik itu juga 
- Sifat bayangan pada cermin cekung yang berada di depan cermin adalah nyata, terbalik.(jika nomor bayangan > nomor benda, bayangan diperbesar, nomor bayangan $<$ nomor benda, bayangan diperkecil

- $\mathrm{F}=$ titik fokus, $\mathrm{O}=$ pusat cermin, $\mathrm{M}=$ titik pusat kelengkungan cermin

\section{Cermin Cembung}
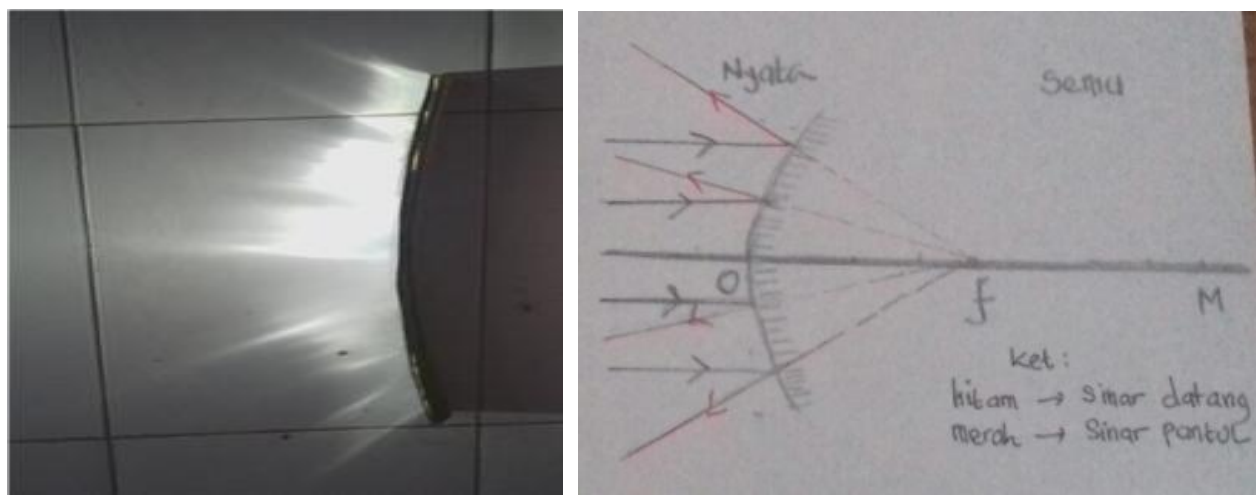

Gambar 4.

Hasil Temuan Cermin Cembung

Dari gambar 4. diatas dapat diuraikan

- Cermin cembung bersifat divergen yaitu menyebarkan cahaya

- Titik fokus terletak di daerah semu (belakang cermin) sehingga sering disebut cermin negatif $(\mathrm{f}=-)$

- 3 sinar istimewa pada cermin cembung, (1) sinar datang sejajar dengan sumbu utama, dipantulkan seolah-olah dari titik fokus, (2) sinar datang menuju titik fokus dipantulkan sejajar sumbu utama, (3) sinar datang menuju titik $\mathrm{M}$ dipantulkan seolah-olah dari titik itu juga

- bayangan pada cermin cembung adalah maya, tegak, dan diperkecil 
- $\mathrm{F}=$ titik fokus, $\mathrm{O}=$ pusat cermin, $\mathrm{M}=$ titik pusat kelengkungan cermin

\section{Aplikasi Praktis dalam Pembelajaran}

Penerapan media cermin pelepah sawit materi sifat cahaya pada cermin datar, cekung dan cembung dalam proses pembelajaran menggunakan model pembelajaran discovery learning. Siswa belajar menemukan konsep dengan praktek langsung dengan media yang telah dibuat perkelompok. Kegiatan belajar jadi sangat aktif di dominasi oleh siswa, guru hanya mengarahkan saja. Siswa begitu antusias dalam kegiatan diskusi terlihat siswa sangat senang ketika mempersentasikan karya yang dibuatnya, ada kepuasan tersendiri bagi siswa karena terlibat langsung dalam pembelajaran ini.

Tabel 1.

Langkah-langkah Pembelajaran Penerapan Media Cermin Pelepah Sawit dengan Model Pembelajaran Discovery Learning

\begin{tabular}{|c|l|ll|}
\hline NO & \multicolumn{1}{|c|}{ FASE } & \multicolumn{1}{c|}{ KETERANGAN } \\
\hline 1 & $\begin{array}{l}\text { Menciptakan Situasi } \\
\text { (simulasi) }\end{array}$ & - & Guru menyampaikan tujuan pembelajaran \\
& & - & Mengamati pohon pelepah sawit, \\
& & kemudian siswa menyampaikan idenya \\
& & dari apa yang dilihat pada pelepah sawit \\
& & dan \\
& & dihubungkan dengan materi \\
& & pembelajaran, guru memotivassi siswa \\
& & Membuat media dari pelepah sawit \\
\hline
\end{tabular}




\begin{tabular}{|c|c|c|}
\hline 2 & Identifikasi Masalah & 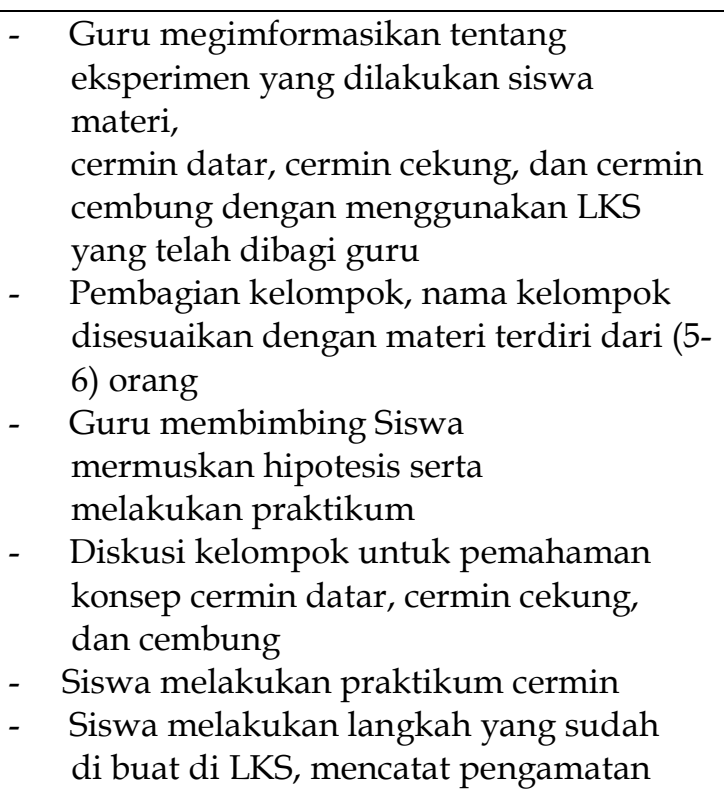 \\
\hline 3 & Pengumpulan Data & $\begin{array}{l}\text { - Siswa mencatat data, dan } \\
\text { menjawab pertanyaan yang tertera } \\
\text { di LKS }\end{array}$ \\
\hline 4 & Pengolahan Data & $\begin{array}{l}\text { - Membuat data hasil pengamatan } \\
\text { media cermin }\end{array}$ \\
\hline 5 & Pembuktian & $\begin{array}{l}\text { - Siswa melakukan diskusi kelompok } \\
\text { - } \quad \text { Tiap kelompok mempersentasikan } \\
\text { hasil diskusi kelompoknya }\end{array}$ \\
\hline 6 & Kesimpulan & $\begin{array}{l}\text { Siswa dan guru melakukan review } \\
\text { hasil pembelajaran cermin }\end{array}$ \\
\hline
\end{tabular}

Media cermin pelepah sawit diterapkan pada proses pembelajaran mata pelajaran IPA pada hari Senin, Jumat yaitu tanggal 2, 6, 9 April 2018 di Kelas VIII-2 SMP Negeri 5 Satu Atap Tanjung Morawa berjumlah 36 orang terdiri dari 19 orang laki-laki dan perempuan 17 orang.

\section{Analisa Data Hasil Aplikasi Praktis Inovasi Pembelajaran}

Dari hasil pengolahan data diperoleh bahwa terjadi peningkatan hasil belajar penggunaan media pelepah sawit dengan model pembelajaran discovery learning. ( $g=0,72$ kategori tinggi). Terjadi 
peningkatan dari hasil pretest $\bar{X}=33,72$ menjadi $\bar{X}=81,94$, dengan ketuntasan sebelumnya $6 \%$ menjadi 81,94 .

Data hasil belajar dapat dilihat pada grafik berikut ini

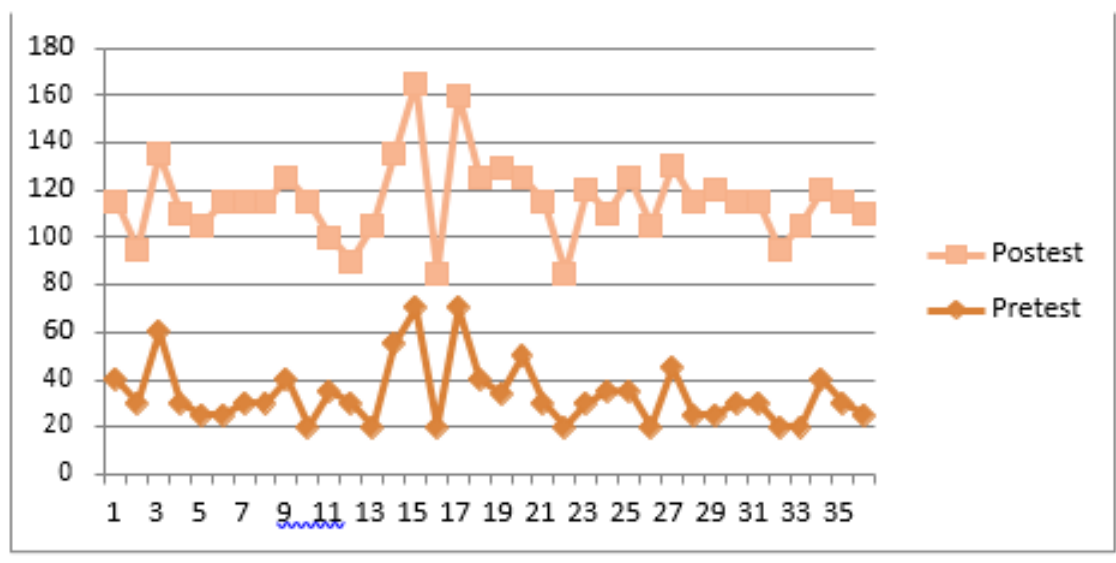

\section{Gambar 5. Grafik Data Hasil Belajar}

Dengan melibatkan siswa langsung dalam pembuatan media, dengan petunjuk dari guru dalam bentuk Lembar Kerja Siswa (LKS), siswa berdiskusi dengan temannya dalam penemuan konsep. Proses pembelajaran juga didukung dengan penerapan pembelajaran inkuiri diharapkan siswa memahami konsep cermin datar, cermin cekung, dan cermin cembung dan pembelajaran menjadi lebih menarik, sehingga terjadi komunikasi yang efektif anatara siswa dan guru. Pembuatan media pembelajaran dengan pelepah kelapa sawit materi cermin dengan discovery learning pada kelas VIII merupakan solusi dalam mengatasi kesulitan siswa pada pembelajaran.

\section{Diseminasi}

Sosialisasi hasil inovasi pembelajaran tentang media cermin datar, cekung, dan cembung dari pelepah sawit diadakan di SMP Negeri 5 Satu Atap Tanjung Morawa tanggal 02 Mei 2018 dan 17 Agustus 2019. 
Kegiatan ini diikuti oleh 5 Sekolah SMP Negeri 1 s/d 5 yang ada di Kecamatan Tanjung Morawa. Kegiatan ini mendapatkan tanggapan positif dari para guru yang hadir. Diseminasi ini juga memotivasi guru untuk dapat menghasillkan karya inovasi dalam pembelajaran IPA dengan memanfaatkan lingkungan sekitar. Hasil inovasi ini juga dibagikan melaui WA group buat guru-guru IA di Kabupaten Deli Serdang.

\section{Analisa Data Hasil Aplikasi Praktis Inovasi Pembelajaran}

Dari hasil pengolahan data diperoleh bahwa terjadi peningkatan hasil belajar penggunaan media pelepah sawit dengan model pembelajaran discovery learning. ( $\mathrm{g}=0,72$ kategori tinggi). Terjadi peningkatan dari hasil pretest $\bar{X}=33,72$ menjadi $\bar{X}=82,08$, dengan ketuntasan sebelumnya $6 \%$ menjadi $89,00 \%$. Lembar observasi siswa yang meliputi desain, pembuatan media, observasi, penyajian dan kreatifitas rata-ratanya 83,45 dengan kategori sangat baik. Peningkatan hasil belajar dengan media cermin pelepah, penilaian sikap dan kinerja siswaapat dilihat pada Gambar 9 berikut ini:
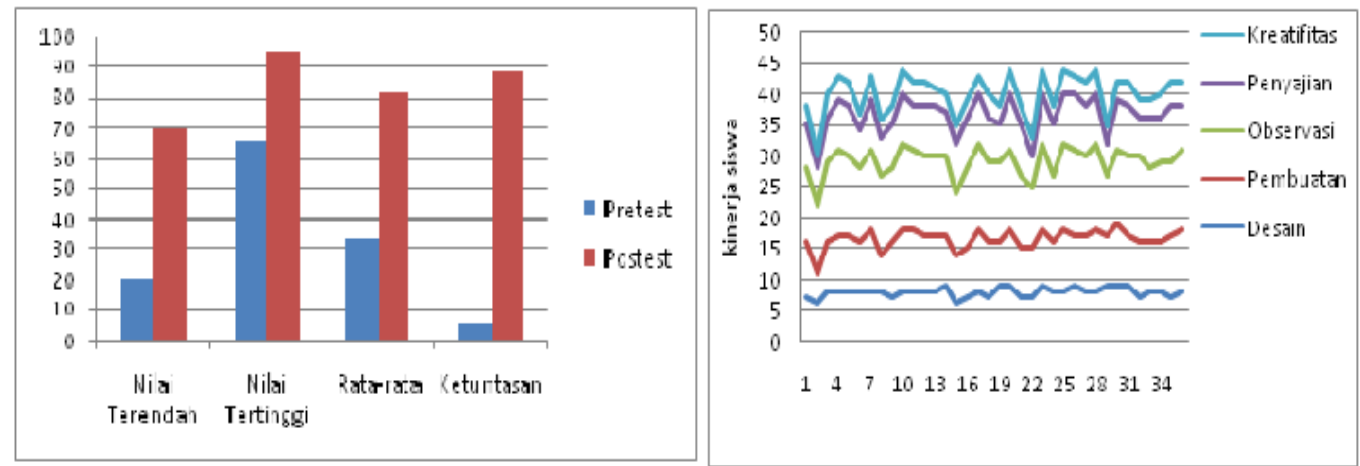

Gambar 6.

Grafik Data Hasil Belajar dan Sikap, Kinerja 


\section{Penutup}

Berdasarkan hasil temuan pengembangan dan penelitian media cermin pelepah sawit dengan model discovery learning, maka media cermin pelepah sawit dapat digunakan pada pembelajaran IPA materi cermin datar, cekung dan cembung. Media cermin pelepah sawit ini layak digunakan dalam pembelajaran IPA. Selain itu Penggunaaan media cermin pelepah sawit dengan model discovery learning dapat meningkatkan hasil belajar siswa. Siswa dapat memahami konsep dengan baik. Dengan penggunaan media ini suasana pembelajaran menjadi menyenangkan, sehingga siswa antusias untuk mengikuti pembelajaran IPA. Proses pengembangan media cermin pelepah sawit ini mampu membangun karakter siswa yaitu sikap ilmiah (disiplin, jujur, kerjasama, perduli lingkungan).

\section{Ucapan Terimakasih}

Ucapan terima kasih kepada semua pihak telah mendukung proses penelitian ini, terutama untuk Kepala Sekolah, teman sejawat dan siswa siswi SMP Negeri 5 Satu Atap Tanjung Morawa.

\section{Daftar Pustaka}

Arikunto, S. (2013), Manajemen Penelitian. Jakarta : Rineka Cipta

Arsyad, A. (2013). Media Pembelajaran.. Jakarta: PT. Raja Grafindo Persada.

Dick, W., \& Carey, L. (2005). The Systematic Design of Instruction. 6 th edition. Pearson: Amerika

Halliday, R. et.al (2010), Fisika Dasar, Edisi Ketujuh Jilid 2. Jakarta PT> Geloara Perkasa

Harlen, W. 1992. The Teaching of Science: Studies in Primary Education. London: David Fulton Publishers. 
Heinzelmann,F. et.al (2015). Adaptive Liquid and Sunlight Redirection. Journal of Architectural Computing, 12(2), 129-153. DOI: 10.1260/1475-472X.12.2.129

Hosnan. (2014). Pendekatan Saintifik dan Konstektual dalam Pembelajaran Abad 21. Bogor: Ghalia Indonesia

Pahan, I. (2012). Panduan Lengkap Kelapa Sawit. Penebar Swadaya : Jakarta

Sani, R.A. (2014). Pembelajaran Saintifik untuk Implementasi Kurikulum 2013. Jakarta : Bumi Aksara

Sanjaya, Wina. (2010). Strategi Pembelajaran Berorientasi Standar Proses Pendidikan. Jakarta : Prenada Media Group

Schunk, H., Dale. Learning Theories (2012) Teori-teori Pembelajaran, Yogyakarta : Pustaka Pelajar.

Singh, Sunita and Yaduvanshi. S. (2015). Constructivism in Science Classroom: Why and How. International Journal of Scientific and Research Publications, Volume 5, Issue 3, March 20151 ISSN 22503153

Sink, Darryl L. (2014). Designs Models and Learning Theories for Adults. American Society for Training and Development.

Slavin, Robert E., (2011). Psikologi Pendidikan Teori dan Praktek Edisi Kesembilan Jilid 1, Jakarta : PT Indeks

Trianto. (2012). Model Pembelajaran IPA, Surabaya : Ikrar Mandiri

Uno. B. Hamzah., (2011) Satria koni, Asesssment Pembelajaran, Jakarta: Bumi Aksara 